\title{
Ion dependence of resting membrane potential of rat spermatids
}

\author{
J. G. Reyes ${ }^{1,2}$, J. Bacigalupo ${ }^{3}$, R. Araya ${ }^{1}$ and D. J. Benos ${ }^{4}$ \\ ${ }^{\mathrm{I}}$ Instituto de Quimica, Universidad Catolica de Valparaiso, Valparaiso, Chile; ${ }^{2}$ Depto Fisiologia y \\ Biofisica, Facultad de Medicina and ${ }^{3}$ Depto de Biologia, Facultad de Ciencias, Universidad de Chile, \\ Santiago, Chile; and ${ }^{4}$ Department of Physiology and Biophysics, The University of Alabama at \\ Birmingham, Birmingham, AL 35294-0005, USA
}

\begin{abstract}
The membrane potential of rat spermatids was estimated as $-22 \pm 2 \mathrm{mV}$ (mean \pm SEM) using three independent methods: using oxonol as a fluorescent membrane potential sensitive probe, from the passive distribution of hydrogen ions and from whole-cell patch-clamp records. The estimated permeability ratios $\mathrm{P}_{\mathrm{K}}+: \mathrm{P}_{\mathrm{Cl}^{-}}$and $\mathrm{P}_{\mathrm{Na}^{+}}: \mathrm{P}_{\mathrm{Cl}^{-}}$of the plasma membrane of rat spermatids were 1.0 and 0.3 , respectively. These data indicate that the high luminal $\mathrm{K}^{+}$concentration found in seminiferous tubules could partially close voltage-sensitive calcium channels in these cells.
\end{abstract}

\section{Introduction}

In spite of the interest in spermatogenesis in animal and human reproduction, very little is known about the general physiological aspects of spermatogenic cells. Their energy metabolism has been well characterized (for example, Mita and Hall, 1982; Nakamura et al., 1982; Grootegoed et al., 1986; 1982; Reyes et al., 1990) and some transport studies of uncharged molecules have been performed (Nakamura et al., 1986). However, intracellular ion homeostasis, membrane potential, and ion transport in these cells have been only partially explored (Kierszenbaum et al., 1971; Hagiwara and Kawa 1984; Reyes et al., 1993).

In mammals, the differentiation stages of spermatogenesis occur in a seminiferous tubule compartment (adluminal), the composition of which is considered to be controlled by the activity of Sertoli cells and the meiotic and postmeiotic spermatogenic cells (Dym and Fawcett, 1970). There are peptides, steroids, and other factors in this adluminal compartment that could determine the permeability properties of the membranes. In this compartment, the ionic gradients responsible for the membrane potential of spermatogenic cells appear to be locally regulated and could play a role in growth and development of these cells. Potassium, an ion to which the membrane potential of many cells is very responsive, is present at a concentration of $50 \mathrm{mmol}^{-1}$ in the seminiferous tubule, that is, 10 times higher than its concentration in plasma (Setchell and Brooks, 1988).

The membrane potential of a cell is an important parameter that determines the rate of entry and the steady-state distribution of many pharmacologically active charged substances (see Scheler and Blank, 1977). It is also a trigger signal for many cellular processes controlled by voltage-sensitive sodium, potassium or calcium channels. Activation or modulation of some of these channels is a general response to the interaction of many extracellular signals with membrane receptors (Benos and Sorscher, 1992). Thus, the resting membrane potential

Received 17 March 1994. could determine the extent of a response by voltage sensitive channels in a cell to external stimuli.

Using zero-current whole-cell patch-clamp measurements, Hagiwara and Kawa (1984) reported that the membrane potentials of rat spermatogenic cells at different stages of development were -10 to $-50 \mathrm{mV}$. However, there have been no accurate determinations of the membrane potential of mammalian spermatids. This value, and its ion dependence, is important because these cells have voltage-sensitive channels, including $\mathrm{Ca}^{2+}$ channels (Hagiwara and Kawa, 1984), the opening and closing of which could determine the rate of entry of $\mathrm{Ca}^{2+}$, a key intracellular regulator in most cells.

We estimated the resting membrane potential of rat spermatids as $-22 \pm 2 \mathrm{mV}$ using three independent methods: (i) using oxonol as a fluorescent membrane potential-sensitive probe; (ii) from the passive distribution of protons and (iii) from whole-cell patch-clamp recordings. The membrane potential of rat spermatids is determined predominantly by $\mathrm{Cl}^{-}$and $\mathrm{K}^{+}$ conductances with a minor contribution by $\mathrm{Na}^{+}$conductance.

\section{Materials and Methods}

\section{Isolation of rat spermatids}

Male Wistar rats ( $300 \mathrm{~g}$ ) obtained either from the University of Valparaiso breeding facilities or from Charles River Laboratories (Wilmington, MA) were maintained in a $12 \mathrm{~h}$ light: $12 \mathrm{~h}$ dark cycle. The rats were killed by cervical dislocation and the testicles excised, decapsulated, and treated with collagenase. The resulting seminiferous tubules were subjected to mechanical disruption. The spermatids were separated in a continuous nonlinear Percoll gradient, as described by Grootegoed et al. (1986) and Reyes et al. (1990), or by unit gravity sedimentation in a BSA gradient as described by Bellve et al. (1977).

\section{Chemicals}

Collagenase, DNAse, Percoll, BSA, cAMP, cGMP, gramicidin, nigericin, valinomycin, carbonyl cyanide $m$-Cl-phenyl 
hydrazone (CCCP), antimycin, 4,4'diisothiocyanostilbene- $2,2^{\prime}$ disulfonic acid (DIDS) and the salts and buffers used were obtained from Sigma Chemical Co. (St Louis, MO). Bis-( 1,3 diethyl) thiobarbiturate trimethine oxonol and $2^{\prime}, 7^{\prime}$-bis-(2carboxyethyl)-5-(and 6) carboxyfluorescein acetoxymethyl ester were obtained from Molecular Probes, Inc. (Eugene, OR).

\section{Determination of the membrane potential of spermatids from fluorescence measurements}

In principle, the estimation of the intra- and extracellular concentrations of any trace charged molecule that distributes at equilibrium across the membrane can be used to monitor the membrane potential of cells. The distribution of such a substance is related to the membrane potential by the Nernst diffusion potential equation:

$$
V_{\mathrm{m}}(i-o)=(\mathrm{RT} / z \mathrm{~F}) \ln \left\{[\text { ion }]_{o} /[\text { ion }]_{i}\right\}
$$

where $V_{\mathrm{m}}$ is the membrane potential; $\mathrm{R}$ is the gas constant; $T$ is the temperature in ${ }^{\circ} \mathrm{K} ; z$ is the ion charge and $\mathrm{F}$ is Faraday's constant.

If this substance can be determined at very low concentrations, its contribution to the membrane potential will be minimal. This is the principle that has been used to determine the membrane potential of cells and organelles using permeable lipophilic ions, ion-selective microelectrodes, radioactively labelled ions, or fluorescent molecules (Hoffman and Laris, 1974; Rink et al., 1980).

Because protons can be determined at concentrations of $100 \mathrm{nmol} 1^{-1}$ or less, and in a range of concentrations compatible with most cellular functions, they can also be used to estimate the value of the membrane potential. The requirement of this measurement is that the ions have to be as close as possible to equilibrium, a proton ionophore has to be provided, and contributions to transmembrane $\mathrm{H}^{+}$gradients from coupled acid-base transport mechanisms and internal sources of hydrogen ions should be minimal.

Membrane potential measurements using bis-(1,3 diethyl)thiobarbiturate trimethine oxonol as a negatively charged fluorescent probe. Oxonol was determined with excitation at $535 \mathrm{~nm}$ and emission at $560 \mathrm{~nm}$ using a $5 \mathrm{~nm}$ slitwidth in a 44 BMPF Perkin Elmer or Delta Scan PTI spectrofluorometer. The fluorescence of $1.5 \mathrm{nmol}$ oxonol $1^{-1}$ was initially measured, and $0.01 \mathrm{ml}$ of a concentrated cell suspension was added to the $3 \mathrm{ml}$ cuvette thermostatically regulated at $34^{\circ} \mathrm{C}$ (final cell concentration

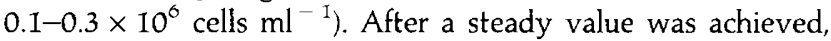
gramicidin $\left(0.4 \mu \mathrm{mol} \mathrm{l}^{-1}\right)$ was added to the cell suspension and a new steady level of fluorescence established. Measurements were performed at different $\mathrm{K}^{+}, \mathrm{Na}^{+}$or $\mathrm{Cl}^{-}$concentrations, achieved by isosmotically changing the $\mathrm{Na}^{+}$or $\mathrm{K}^{+}$concentration in the external medium by replacement of $\mathrm{Na}^{+}$with $\mathrm{N}$-methyl-D-glucamine and $\mathrm{K}^{+}$with $5 \mathrm{mmol} \mathrm{Na}{ }^{+} \mathrm{I}^{-1}$ and changes in $\mathrm{Cl}^{-}$concentrations were obtained by substitution with sodium gluconate. In some cases, the measurements were performed by successive additions of aliquots of a concentrated solution of the probe in dimethylsulfoxide to obtain a fluorescence versus concentration curve. Unless stated otherwise, ali the fluorescence and patch-clamp measurements were performed at an external $\mathrm{pH}$ of 7.4 , buffered with $20 \mathrm{mmol} \mathrm{l}^{-1}$.

Intracellular $\mathrm{pH}$ measurements. The intracellular $\mathrm{pH}$ of the spermatids was estimated using the fluorescent probe $2^{\prime}, 7^{\prime}$-bis(2-carboxyethyl)-5-(and 6)-carboxyfluorescein (BCECF). The cells were loaded with the membrane permeable acetoxy methyl BCECF $\left(2 \mu \mathrm{mol} \mathrm{l}^{-1}\right)$ for $20 \mathrm{~min}$ at $34^{\circ} \mathrm{C}$. Fluorescence was measured by emission at $535 \mathrm{~nm}$ and alternate excitations at 445 and $505 \mathrm{~nm}$. The probe was calibrated intracellularly in Krebs-Henseleit solution with $120 \mathrm{mmol} \mathrm{K}^{+} \mathrm{1}^{-1}$ and $10 \mu \mathrm{g}$ nigericin $\mathrm{ml}^{-1}$ at different $\mathrm{pH}$ values, and the fluorescence ratio was measured at excitations of 505:445 nm. The intracellular calibration of the probe produced, on average, only a $0.05 \mathrm{pH}$ unit shift toward alkaline $\mathrm{pH}$ values compared with the probe in solution when the cells were permeabilized with digitonin (Owen, 1992). Values of fluorescence ratios at steady state were converted to $\mathrm{pH}_{\mathrm{i}}$ using a standard regression line for $B C E C F$ calibration with nigericin.

Extracellular $\mathrm{pH}$ was determined in the cell suspension before and at the end of each experiment using a combined glass electrode and a Cole- $\mathrm{Parmer} \mathrm{pH}$ meter.

\section{Whole cell patch-clamp measurements of spermatid resting membrane potentials}

The zero current membrane potential was determined in current clamp mode when passing from cell-attached to the whole-cell configuration of the patch-clamp technique (Warner Instruments Corp., Model PC-50, Hamden, CT). Patch pipettes were made of borosilicate glass and filled with $140 \mathrm{mmol} \mathrm{KCl}$ $1^{-1}, 5 \mathrm{mmol} \mathrm{MgCl}_{2} \mathrm{l}^{-1}, 5 \mathrm{mmol}$ EGTA $\mathrm{l}^{-1}$ and $5 \mathrm{mmol}$ Hepes $1^{-1}, \mathrm{pH} 7.4$. Typical values of pipette resistance were 2.5-5 Mohms. Seal resistances ranged between 5 and $10 \mathrm{Gohms}$. The cells, attached to a polylysine-covered coverslip, were viewed under phase contrast microscopy. Cells with a diameter of 10-12 $\mu \mathrm{m}$ were chosen which showed the typical nucleus contour of rat spermatids.

Typical cell input resistances and cell capacitances were 2-5 Gohms and 3-4 pF, respectively.

\section{Ion content of rat spermatids and solutions}

The ion content of the rat spermatids was determined by preincubation of the cells in Krebs-Henseleit buffer-lactate medium at $34^{\circ} \mathrm{C}$ under an atmosphere of $95 \% \mathrm{O}_{2}: 5 \% \mathrm{CO}_{2}$ for $15 \mathrm{~min}$. Five microcuries ${ }^{3} \mathrm{H}_{2} \mathrm{O} \mathrm{ml}{ }^{-1}$ and $10 \mu \mathrm{Ci}$ of $\left[{ }^{14} \mathrm{C}\right]$ polyethylene glycol ml $\mathrm{m}^{-1}\left(\mathrm{M}_{\mathrm{r}} 4000\right)$ were added to the cells, and $30 \mathrm{~s}$ later the cells were centrifuged through dibutylphthalate at $14000 \mathrm{~g}$ for $1 \mathrm{~min}$. The microfuge tube above the dibutylphthalate was washed with deionized water. The pellets were dissolved in $500 \mu \mathrm{l}$ of $0.1 \%(\mathrm{v} / \mathrm{v})$ cation-free Triton X-100 and $10 \mathrm{mmol} \mathrm{LiCl} \mathrm{l}^{-1}$, and aliquots were taken for liquid scintillation counting of ${ }^{3} \mathrm{H}$ and ${ }^{14} \mathrm{C}$, and for $\mathrm{Na}^{+}, \mathrm{K}^{+}$and $\mathrm{Cl}^{-}$ determination. $\mathrm{Na}^{+}$and $\mathrm{K}^{+}$were determined by atomic absorption spectrophotometry and chloride was determined using a coulombimeter. The ion concentration in the cells was 


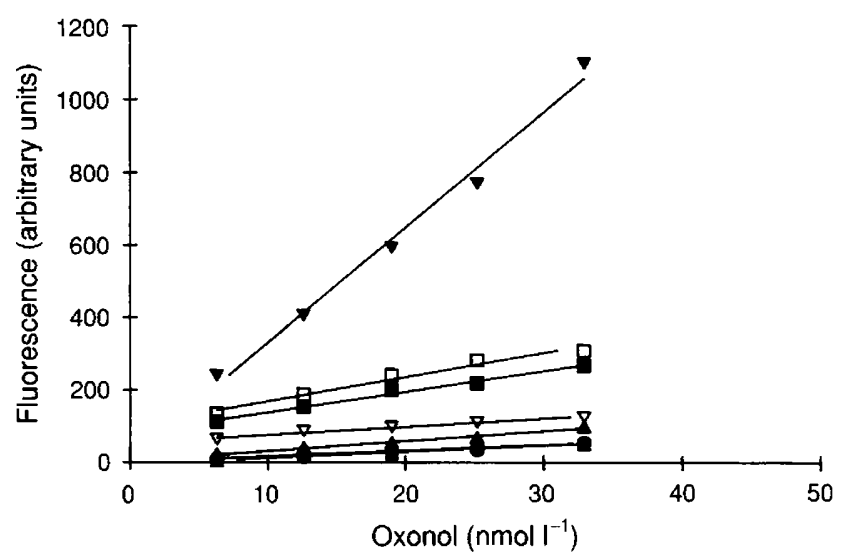

Fig. 1. Fluorescence intensity of Krebs-Henseleit solutions with different $\mathrm{K}^{+}$concentrations in the presence $(\mathbf{4}: 0.1,7: 4.6,1: 20$, and - $120 \mathrm{mmol} \mathrm{K}^{+} \mathrm{1}^{-1}$ ) and absence ( $0.1, \bullet: 20$, and : $120 \mathrm{mmol}$ $\left.\mathrm{K}^{+} \mathrm{l}^{-1}\right)$ of valinomycin $\left(0.8 \mu \mathrm{mol} \mathrm{l}^{-1}\right)$ or with $(\boldsymbol{v})$ digitonin-treated rat spermatids ( $20 \mu \mathrm{g}$ digitonin $\mathrm{ml}^{-1}, 0.4 \times 10^{6}$ cells $\mathrm{ml}^{-1}$ ) in suspension as a function of oxonol concentration.

calculated using the ion content in the pellets and the determination of intracellular water (see also Reyes et al., 1993).

\section{Statistical analyses}

Unless stated otherwise, the values reported are expressed as means $\pm S D$. The data were tested using Bartlett's test for equality of variances, and subsequently tested in a two-tailed Student's $t$ test or Welch's modified $t$-like test or one-way ANOVA ( $\mathrm{Li}, 1964)$. Nonlinear regression analysis of the membrane potential estimates versus ion concentration, using the Goldman-Hodgkin-Katz equation (Goldman, 1943; Hodgkin and Katz, 1949), were performed using the Enzfitter software package (Elsevier Biosoft, Cambridge, UK). The data were considered significant at $P<0.05$.

\section{Results}

\section{Measurements with oxonol}

Adding cells to an oxonol solution in Krebs-Henseleit buffer increased the fluorescence, as expected from previous studies in which fluorescence was enhanced by binding of the dye to cell components (for example, Rink et al., 1980).

Oxonol appears to form ion pairs in the presence of valinomycin and $\mathrm{K}^{+}$, as has been described for the interaction of valinomycin and 8-anilino-I-naphthalenesulfonate (Feinstein and Felsenfeld, 1971). The formation of an ion pair is accompanied by an increase in fluorescence. The fluorescence yield increased when the $\mathrm{K}^{+}$concentration was increased at a given concentration of valinomycin $\left(0.8 \mu \mathrm{mol} \mathrm{l}^{-1}\right.$, Fig. 1). This interaction between $\mathrm{K}^{+}$-valinomycin and oxonol results in an overestimate of the amount of dye bound to the cells owing to the fluorescence yield by extracellular oxonol- $\mathrm{K}^{+}-$ valinomycin.

When the cells were added after interaction of oxonol with $\mathrm{K}^{+}$-valinomycin, a slow increase in fluorescence was observed (Fig. 2a), suggesting that the dye binds to the cells with higher affinity than to $\mathrm{K}^{+}$-valinomycin, and that oxonol was being displaced from the ion pairs formed. Conversely, if the cells were exposed to the dye first, the increase in fluorescence occurred faster (Fig. 2b), again suggesting that dye desorption from ion pairs causes the slow increase in fluorescence observed in the previous case. When valinomycin was added after the cells, a further increase in fluorescence was observed that gradually returned toward basal values (Fig. 2 b).

The cation ionophore gramicidin does not interact with oxonol (Grinstein et al., 1984) and hence can be used to calibrate the dye in the cells. The calibration of oxonol requires the estimation of the membrane potential as established by adding gramicidin to the cell suspension. The gramicidininduced potential in rat spermatids was estimated using the ion content of the cells, and permeability ratios for $\mathrm{P}_{\mathrm{K}}+\mathrm{P}_{\mathrm{Na}}+$ and

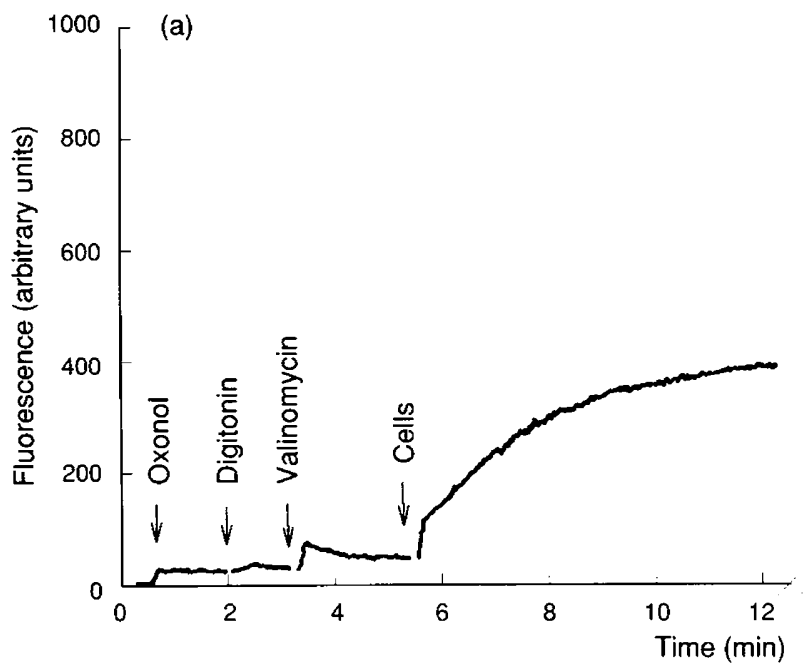

\author{
(b)
}

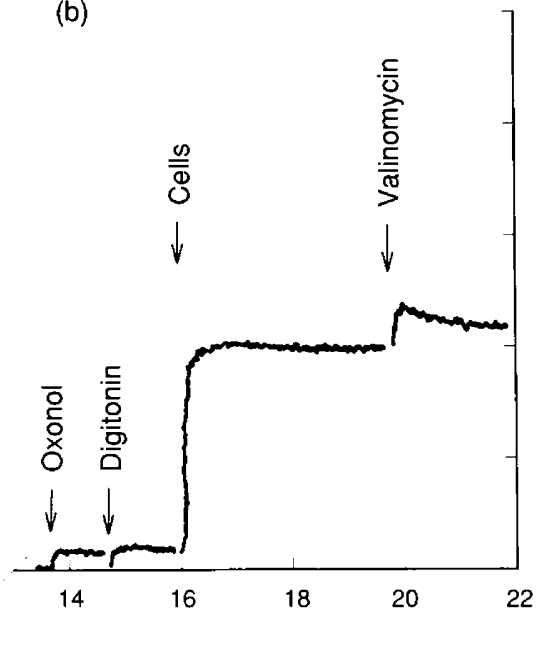

Fig. 2. Time course of the fluorescence intensity of $1.5 \mathrm{nmol}$ oxonol $\mathrm{l}^{-1}$ in Krebs-Henseleit medium and its interaction with valinomycin $\left(0.8 \mu \mathrm{mol} \mathrm{l^{-1 } )}\right.$ and rat spermatids. (a) When spermatids were added after valinomycin, the increase in fluorescence occurred more slowly than (b) when the cells were added before valinomycin. 
$\mathrm{P}_{\mathrm{Cl}^{-}}: \mathrm{P}_{\mathrm{K}^{+}}$of 1.6 (Lauger, 1973) and 0.6, respectively (see below). The ion content of rat spermatids (in mmol $\mathrm{l}^{-1}$ ) were $107 \pm 11(n=10)$ for $\mathrm{K}^{+}, 45 \pm 7(n=11)$ for $\mathrm{Na}^{+}$, and $60 \pm 10(n=10)$ for $\mathrm{Cl}^{-}$. A representative curve for the calibration of oxonol fluorescence by varying the ion composition in the external medium in the presence of $0.4 \mu \mathrm{mol}$ gramicidin $\mathrm{l}^{-1}$ is given (Fig. 3a). The reported fluorescence values in Fig. 3a are those obtained $30 \mathrm{~s}$ after gramicidin was added to the cells in a stirred cuvette. Calibration curves were performed on each batch of cells used in the membrane potential measurements, because of the difficulties in precisely reproducing the cell density in different preparations.

The resting membrane potential of rat spermatids in KrebsHenseleit medium was estimated by interpolation in the calibration curve of the fluorescence values after equilibration of the cells with oxonol. The membrane potential of rat spermatids in these conditions was $-25 \pm 6 \mathrm{mV}(n=13)$. The ion dependence of the spermatid membrane potential when extracellular $\mathrm{Na}^{+}, \mathrm{K}^{+}$or $\mathrm{Cl}^{-}$were varied and the rest of the ion composition was constant is shown (Fig. 3b). Fitting of the data for variable $\mathrm{Na}^{+}$to the Goldman-Hodgkin-Katz equation gave values for $\mathrm{P}_{\mathrm{Na}}: \mathrm{P}_{\mathrm{Cl}}$ and $\mathrm{P}_{\mathrm{K}^{+}}: \mathrm{P}_{\mathrm{Cl}}$ - of $0.3 \pm 0.1$ and $0.7 \pm 0.2$, respectively. The value of $\mathrm{P}_{\mathrm{Na}^{+}}: \mathrm{P}_{\mathrm{Cl}^{-}}$obtained above was used to estimate $\mathrm{P}_{\mathrm{K}^{+}}: \mathrm{P}_{\mathrm{Cl}^{-}}$for various $\mathrm{K}^{+}$or $\mathrm{Cl}^{-}$ concentrations (three different ion concentrations each). The values obtained were $0.9 \pm 0.3$ and $1.0 \pm 0.1$ for variable $\mathrm{K}^{+}$ and $\mathrm{Cl}^{-}$, respectively.

The resting membrane potential of rat spermatids was not modified either by dibutyryl cyclic AMP or by GMP

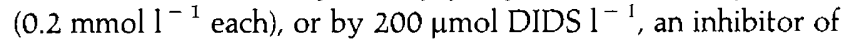
epithelial chloride channels (not shown).

Estimation of membrane potentials using the equilibrium distribution of protons in rat spermatids

The distribution of a univalent cation at equilibrium should follow Eqn (1), which, for protons becomes:

$$
V_{\mathrm{m}}=60\left(\mathrm{pH}_{i}-\mathrm{pH}_{o}\right) \text { at } 34^{\circ} \mathrm{C} \text {. }
$$

Thus, from measurements of intracellular $\mathrm{pH}$, using fluorescence ratio measurements with BCECF and extracellular $\mathrm{pH}$ measurements performed with a $\mathrm{pH}$ electrode, it is possible to estimate membrane potentials from distribution of protons at equilibrium.

The proton permeability of the spermatid membranes was increased by the addition of $1 \mu \mathrm{mol}$ carbonyl cyanide $m-\mathrm{Cl}$ phenylhydrazone $\mathrm{I}^{-1}(\mathrm{CCCP})$ to increase the rate of proton equilibration. Higher CCCP concentrations $\left(10 \mu \mathrm{mol} \mathrm{I}{ }^{-1}\right)$ produced a depolarization $(5 \mathrm{mV})$ estimated with oxonol measurements. Furthermore, a high-affinity blocker of the $\mathrm{Na}^{+}-\mathrm{H}^{+}$ exchanger, ethyl isopropyl amiloride $\left(16 \mu \mathrm{mol} \mathrm{l}^{-1}\right)$, was used to inhibit this transport system in the spermatids. In addition, to avoid some of the important sources of metabolic acid in these cells (Reyes et al., 1990), solutions without glucose and bicarbonate and including antimycin $\left(0.3 \mu \mathrm{g} \mathrm{ml}^{-1}\right)$ were used.

Addition of CCCP, a proton ionophore, lowered the intracellular $\mathrm{pH}$ and a new steady-state was reached after approximately $10 \mathrm{~min}$ (Fig. 4a). Subsequent addition of valinomycin
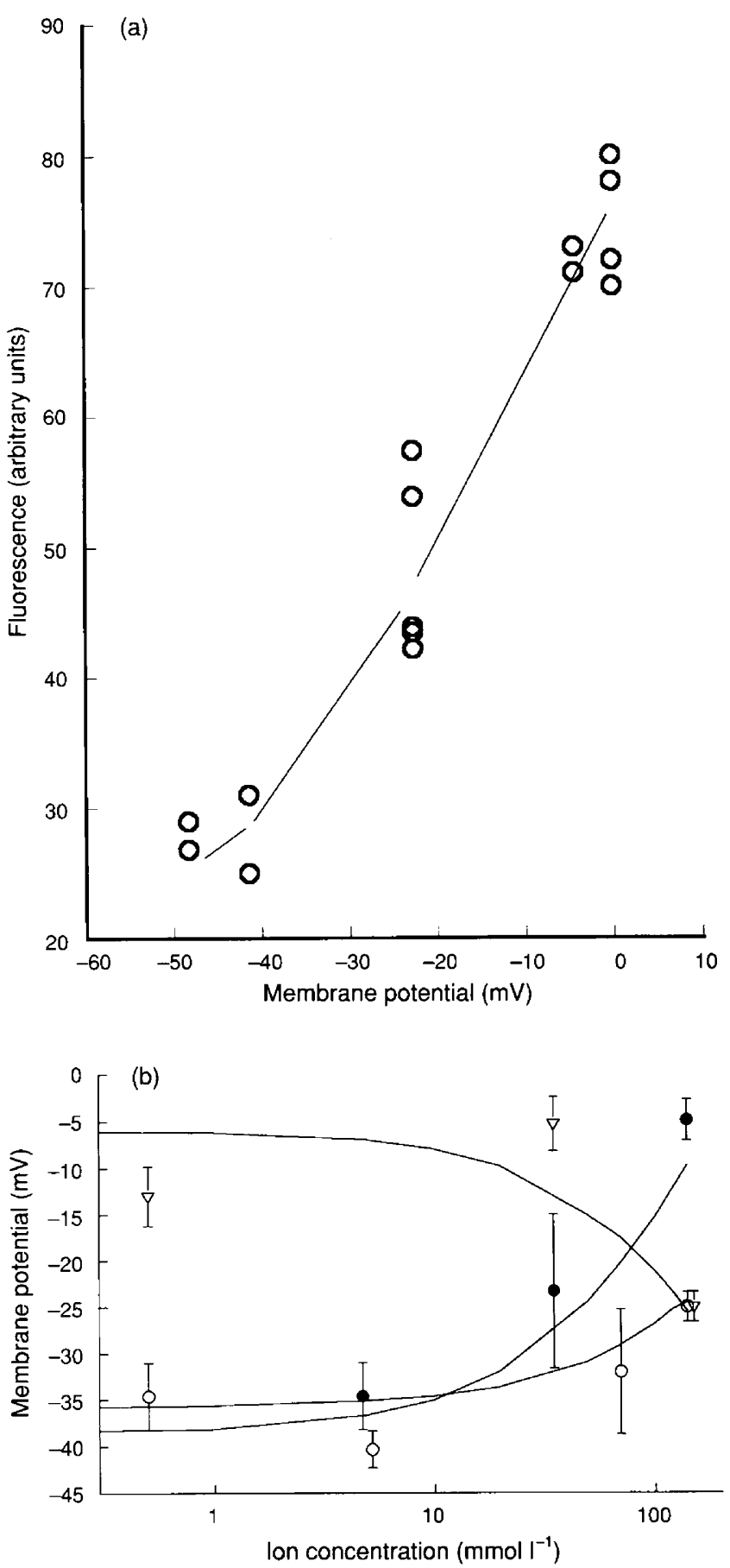

Fig. 3. (a) Calibration curve for oxonol fluorescence versus gramicidin-induced membrane potential of rat spermatids at $34^{\circ} \mathrm{C}$. Oxonol and gramicidin concentrations were $1.5 \mathrm{nmol}^{-1}$ and $0.4 \mu \mathrm{mol} \mathrm{l}^{-1}$, respectively. Cell concentration was approximately $0.2 \times 10^{\circ}$ cells ml ${ }^{-1}$. Measurements were taken $30 \mathrm{~s}$ after addition of gramicidin. (b) Membrane potential of rat spermatids estimated from oxonol measurements as a function of the ion composition of the external solution. Concentrations of $\mathrm{Cl}^{-}(\nabla), \mathrm{Na}^{+}(\mathrm{C})$ and $\mathrm{K}^{+}(\bullet)$ were varied by isosmotic replacement with gluconate or $N$-methyl-Dglucamine, maintaining the rest of the ion composition and $\mathrm{pH}$ constant. 


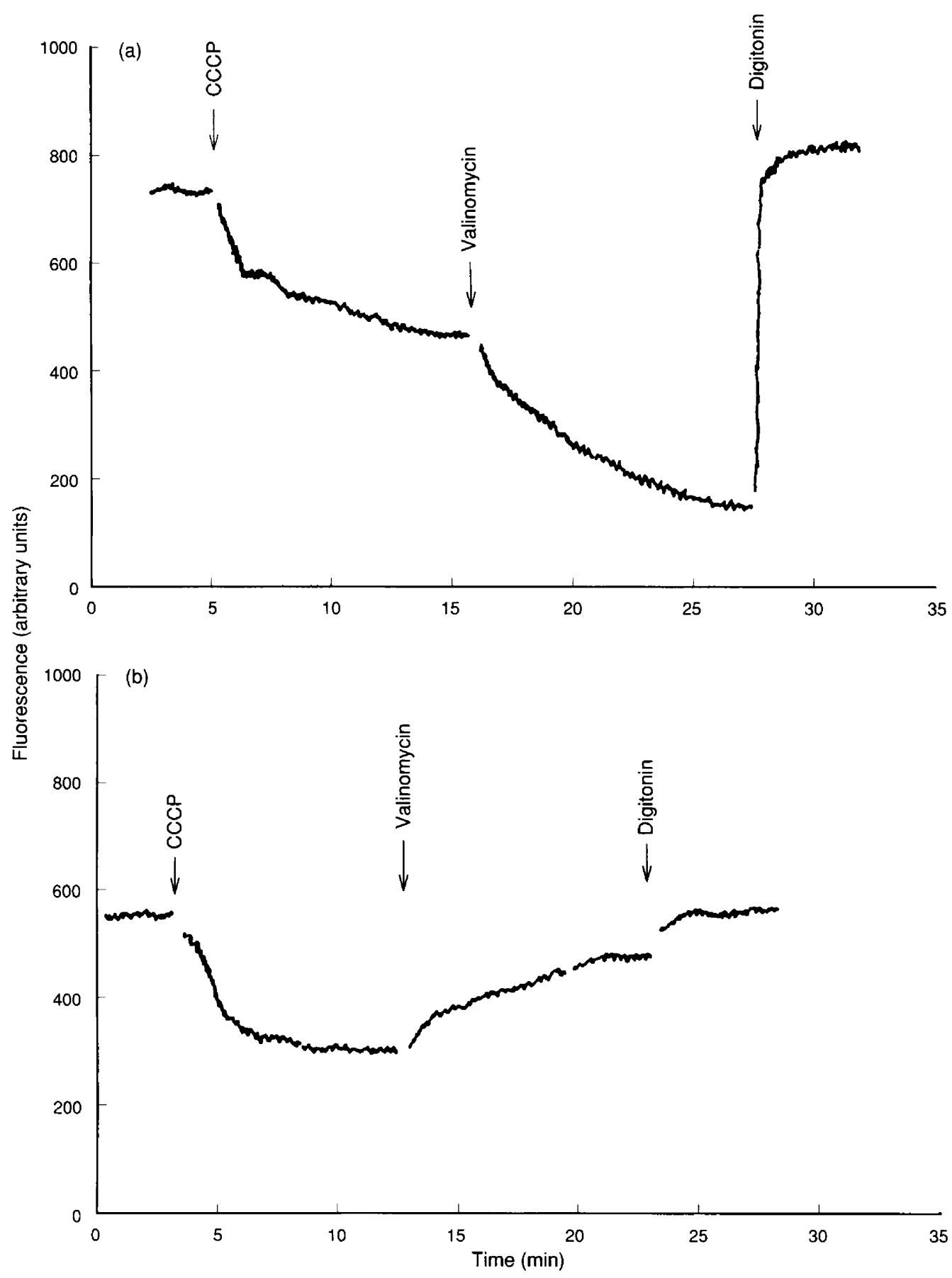

Fig. 4. (a) Fluorescence intensity of intracellular $2^{\prime}, 7^{\prime}$-bis-(2-carboxyethyl)-5-(and 6) carboxy fluorescein (BCECF, $0.4 \times 10^{\circ}$ cells ml ${ }^{-1}$ ) added to rat spermatids versus time at an extracellular $\mathrm{K}^{+}$concentration of $4.6 \mathrm{mmol}^{-1}$, $\mathrm{pH} 7.35$ and $34^{\circ} \mathrm{C}$. Carbonyl cyanide m-chloro-phenyl hydrazone (CCCP), a proton ionophore, valinomycin $\left(0.8 \mu \mathrm{mol} \mathrm{l}^{-1}\right)$, and digitonin $\left(20 \mu \mathrm{g} \mathrm{ml}^{-1}\right)$ were added sequentially. (b) Fluorescence intensity of intracellular $\mathrm{BCECF}$ versus time at an extracellular $\mathrm{K}^{+}$concentration of $140 \mathrm{mmol} \mathrm{l}^{-1}$.

made the intracellular $\mathrm{pH}$ even lower, indicating that the protons distribute across the membrane according to the expected hyperpolarized potential established by valinomycin. This fact was confirmed in experiments with $140 \mathrm{mmol} \mathrm{K}^{+} 1^{-1}$ in the external medium (Fig. 4b), where the addition of valinomycin shifted the intracellular $\mathrm{pH}$ to higher values.
Adding digitonin $\left(20 \mu \mathrm{g} \mathrm{ml}^{-1}\right)$ drove the fluorescence ratio towards values of extracellular $\mathrm{pH}$, as expected from the leak of the probe from the cells or equilibration of protons at zero membrane potential. Control measurements of fluorescence performed in the supernatant after centrifugation of the cells, and at all $\mathrm{K}^{+}$concentrations, showed that extracellular BCECF 


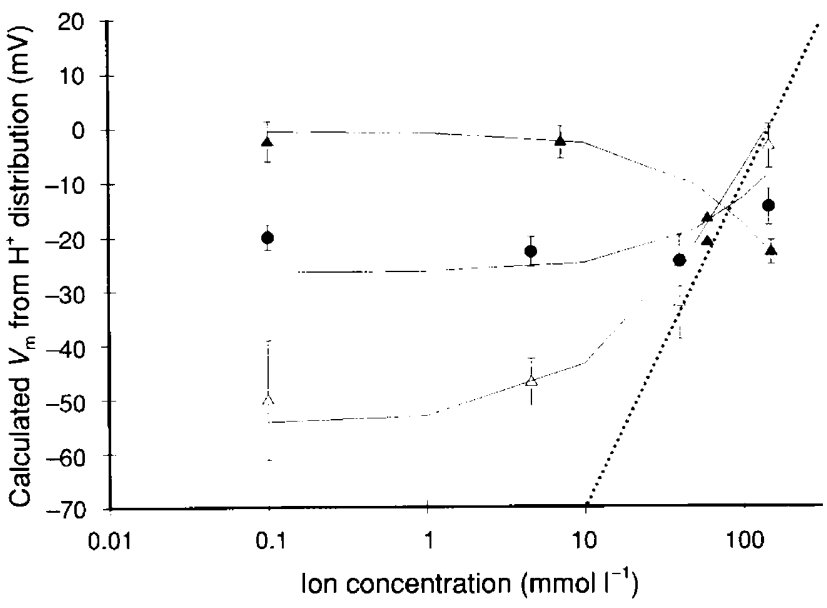

Fig. 5. Calculated membrane potentials $\left(V_{\mathrm{m}}\right)$ of rat spermatids and the changes induced by extracellular potassium $(\bullet)$ alone or $(\therefore)$ with valinomycin added, or ( 1 ) extracellular chloride. The continuous lines represent the fitting of the Goldman-Hodgkin-Katz equation for $\mathrm{P}_{\mathrm{Na}^{+}}: \mathrm{P}_{\mathrm{Cl}^{-}}=0.3$ and $\mathrm{P}_{\mathrm{K}^{+}}: \mathrm{P}_{\mathrm{Cl}}$ of $1.0\left(\mathrm{~K}^{+}\right), 5.5\left(\mathrm{~K}^{+}\right.$plus valinomycin) and $0.8\left(\mathrm{Cl}^{-}\right)$. The dotted line (...) represents the Nernst equation with a slope of $60 \mathrm{mV}$ per decade.

fluorescence contributed less than $10 \%$ to the total fluorescence (not shown).

The membrane potential of rat spermatids calculated from proton distribution experiments was $-21 \pm 7(n=4)$ at very low extracellular $\mathrm{Na}^{+}\left(<0.5 \mathrm{mmol} \mathrm{l}^{-1}, n\right.$-methyl-D-glucamine replacement).

When $\mathrm{Cl}^{-}$was replaced by an impermeant anion (gluconate), a marked effect on the membrane potential of the spermatids was observed (Fig. 5). These results suggest that the membrane potential of rat spermatids is given by a $\mathrm{Cl}^{-}$conductance with some degree of contribution from a $\mathrm{K}^{+}$permeability. The continuous line was calculated for a variable $\mathrm{Cl}^{-1}$ concentration using the Goldman-HodgkinKatz equation, the basal ion content of rat spermatids, and fitted $\mathrm{P}_{\mathrm{K}^{+}}: \mathrm{P}_{\mathrm{Cl}}$ and $\mathrm{P}_{\mathrm{Na}}+\mathrm{P}_{\mathrm{Cl}}$ of $0.8 \pm 0.1$ and $0.3 \pm 0.1$, respectively.

The membrane potential of spermatid calculated from proton distribution, as a function of the extracellular $\mathrm{K}^{+}$concentration $\left(\mathrm{Na}^{+}\right.$replacement) in the presence and absence of valinomycin, is also shown (Fig. 5). At $\mathrm{K}^{+}$concentrations higher than $60 \mathrm{mmol} \mathrm{l}^{-1}$, the $\mathrm{H}^{+}$distribution reported $V_{\mathrm{m}}$ changes in the expected range for a $\mathrm{K}^{+}$equilibrium potential. At low $\mathrm{K}^{+}$concentrations it is likely that the $\mathrm{Cl}^{-}$conductance (see below) became a major factor in determining the membrane potential of rat spermatids. The continuous line represents the Goldman-Hodgkin-Katz equation using the basal ion content of rat spermatids, a $\mathrm{P}_{\mathrm{Na}^{+}}: \mathrm{P}_{\mathrm{Cl}^{-}}=0.3$ and a $\mathrm{P}_{\mathrm{K}^{+}}: \mathrm{P}_{\mathrm{Cl}^{-}}$of 5.5. The resting membrane potential of rat spermatids in Krebs-Henseleit solution estimated from proton distribution measurements was $-20 \pm 4 \mathrm{mV}(n=6)$.

In the absence of valinomycin, the reported membrane potential was less sensitive to changes in the extracellular $\mathrm{K}^{+}$ concentration (Fig. 5), except at $140 \mathrm{mmol} \mathrm{l}^{-1} \mathrm{~K}^{+}$, where the estimated $V_{\mathrm{m}}$ was significantly smaller $(P<0.05$, two tailed Student's $t$ test) than at any other $\mathrm{K}^{+}$concentration tested. The continuous line in the absence of valinomycin was calculated for a variable $\mathrm{K}^{+}$concentration using the Goldman-Hodgkin-Katz equation, the basal ion content of rat spermatids, a $\mathrm{P}_{\mathrm{Na}^{+}}: \mathrm{P}_{\mathrm{Cl}^{-}}=0.3$ and a $\mathrm{P}_{\mathrm{K}}+: \mathrm{P}_{\mathrm{Cl}^{-}}$ratio of 1.0.

Estimations from proton distribution of the membrane potential of rat spermatids in the presence of $0.4 \mu \mathrm{mol}$ gramicidin $1^{-1}$ in solutions of different ion compositions, and assuming a $\mathrm{P}_{\mathrm{K}^{+}}: \mathrm{P}_{\mathrm{Na}^{+}}$of 1.6 , allows an estimation of a $P_{C l}: P_{N a}+$ ratio of $0.6 \pm 0.2(n=4)$ under these conditions. This value was used throughout our theoretical estimations of gramicidin-induced membrane potentials (see oxonol measurements).

Estimations of resting membrane potentials of rat spermatids using whole-cell patch-clamp measurements

The membrane potential of rat spermatids was measured after passing from cell-attached to whole-cell configuration in zero current clamp mode in five cells from four different cell preparations. The resting membrane potential was $-27 \pm 18 \mathrm{mV}$ (mean \pm SEM).

\section{Discussion}

The use of lipophilic ions for membrane potential determinations presents some drawbacks, for example binding of the lipophilic ions to membranes or intracellular components, and metabolic effects of the lipophilic ions (see Johnstone et al., 1982 and Smith, 1982 for discussion). Similarly, estimation of the true membrane potential using $\mathrm{H}^{+}$distribution is subject to uncertainties. The cells are in the presence of a proton ionophore (and antimycin) which inhibits mitochondrial ATP production and ATP production could be a necessary cell regulator for some ion conductive pathways in the cell membrane. In addition, a decrease of intracellular $\mathrm{pH}$ when protons become distributed according to the membrane potential could close or open $\mathrm{pH}$ sensitive ion pathways; and there is always some uncertainty about whether the new $\mathrm{pH}_{\mathrm{i}}$ reached is a new steady-state or true equilibrium. Steps were taken to minimize sources of metabolic protons by removing glucose as a likely source of acid production, using antimycin to stop acid production in Krebs' cycle, by removing bicarbonate as a buffer in the cells, and blocking the $\mathrm{Na}^{+}-\mathrm{H}^{+}$exchanger with ethyl isopropyl amiloride. Hence, the membrane potential values reported using the above mentioned methods should represent good estimates. However, the use of patch-clamp techniques permits a direct measurement of the resting membrane potential of cells. Our data using patch-clamp recordings are in good agreement with the values obtained using proton distribution measurements or oxonol distribution data. Statistical analysis of the data between groups shows that they are not significantly different from each other, thus validating the use of non-invasive dye and $\mathrm{H}^{+}$distribution ratios as adequate ways of estimating resting $V_{\mathrm{m}}$ in rat spermatids. However, as pointed out by Hagiwara and Kawa (1984), the determination of the membrane potential in small cells has a systematic error because of the comparable values between the cell membrane resistance and the seal resistance of the patch pipette. Thus, our measurements using zero-current patch-clamp recordings of the membrane potential would be about $5-50 \%$ less negative than 
the true membrane potential of the cells. The permeability ratios $\mathrm{P}_{\mathrm{K}^{+}}: \mathrm{P}_{\mathrm{Cl}^{-}}$and $\mathrm{P}_{\mathrm{Na}^{+}}: \mathrm{P}_{\mathrm{Cl}^{-}}$obtained using oxonol measurements ( $1.0 \pm 0.1$ and $0.3 \pm 0.1$, respectively) were not significantly different $(P<0.05)$ from the ratios obtained using intracellular $\mathrm{pH}$ measurements $\langle 0.8 \pm 0.1$ and $0.3 \pm 0.1$, respectively). We also attempted to use the cationic fluorescent probe 3,3'dipropylthio-dicarbocyanine iodide $\left(\mathrm{DiSC}_{3}\right)$ at $200 \mathrm{nmol}$ $1^{-1}$ (Hoffman and Laris, 1974) to estimate the membrane potential of rat spermatids. However, addition of valinomycin to the cell suspension equilibrated with the dye produced an increase in the dye fluorescence at all the $\mathrm{K}^{+}$concentrations used $\left(0.1-140 \mathrm{mmol} \mathrm{l}^{-1}\right.$ ) (not shown). This effect seems to reflect mitochondria-related depolarization induced by valinomycin. $\mathrm{DiSC}_{3}$ has been shown to enter mitochondria and inhibit mitochondrial respiration (Montecucco et al., 1979). For these reasons, $\mathrm{DiSC}_{3}$ was rejected as a suitable probe for estimations of the membrane potential in rat spermatids.

If the potential in rat spermatids is set to $-25 \mathrm{mV}$ by the $\mathrm{Cl}^{-}$and $\mathrm{K}^{+}$conductances, it can be predicted that the equilibrium intracellular $\mathrm{Cl}^{-}$concentration should be $57 \mathrm{mmol}$ $1^{-1}$, a value close to that found from cell chloride content measurements by coulombimetry. Steady-state values of intracellular $\mathrm{K}^{+}$of $110 \mathrm{mmol} \mathrm{I}^{-1}$ coupled with a measurable $\mathrm{K}^{+}$ electrogenic permeability, and a membrane potential of $-25 \mathrm{mV}\left(V_{\mathrm{m}}-V_{\mathrm{K}^{+}}=+58 \mathrm{mV}\right)$ implies the operation of active transport systems for potassium when the cells are bathed in solutions of low $\left(4.6 \mathrm{mmol} \mathrm{l}^{-1}\right)$ extracellular $\mathrm{K}^{+}$. However, increasing extracellular $\mathrm{K}^{+}$to $40-50 \mathrm{mmol} \mathrm{l}^{-1}$ would place this ion in conditions close to equilibrium. Whether the high $\mathrm{K}^{+}$content of the seminiferous tubule (Setchell and Brooks, 1988) could be an energy-saving strategy for the spermatozoa being released to the seminiferous tubule lumen remains to be determined.

It can also be predicted that the high luminal $\mathrm{K}^{+}$concentration in the seminiferous tubule $\left(50 \mathrm{mmol} \mathrm{l}^{-1}\right)$ would induce a decrease of the membrane potential of rat spermatids to $-17 \mathrm{mV}$. This depolarization could trigger the closing of $\mathrm{Ca}^{2+}$ channels in the plasma membranes of rat spermatids (Hagiwara and Kawa, 1984). The closing of $\mathrm{Ca}^{2+}$ channels in the plasma membrane can induce a decrease in intracellular $\mathrm{Ca}^{2+}$, which, in turn, could be both a signal for differentiation processes in these cells or a signal that determines a metabolically dormant state, until external regulators (for example, epididymal peptides or egg-envelope molecules) could again activate $\mathrm{Ca}^{2+}$ entry.

The authors thank C. T. Starr and A. J. Harter for secretarial help. This work was supported by funds from Fundacion Andes, UCV 125706 and NIH Grant DK 37206.

\section{References}

Bellve AR, Millette CF, Bhatnagar YM and O'Brien DA (1977) Dissociation of the mouse testis and characterization of isolated spermatogenic cells journal of Histochemistry and Cytochemistry 25 480-494

Benos DJ and Sorscher EJ (1992) Transport proteins. Ion channels. In The Kidney: Physiology and Patho Physiology pp 587-623 Eds DW Seldin and G Giebisch. Raven Press Ltd, New York
Dym M and Pawcett D (1970) The blood-testis barrier in the rat and the physiological compartmentation of the seminiferous tubule epithelium Biology of Reproduction 3 308-325

Feinstein MB and Felsenfeld H (1971) The detection of ionophores antibioticcation complexes in water with fluorescent probes Proceedings of the National Academy of Sciences, USA 68 2037-2041

Goldman DE (1943) Potential impedence and rectification in membranes Journal of General Physiology 27 37-60

Grinstein S, Goetz JD and Rothstein A (1984) ${ }^{22} \mathrm{Na}^{+}$fluxes in thymic lymphocytes. I. $\mathrm{Na}^{+} / \mathrm{Na}^{+}$and $\mathrm{Na}^{+} / \mathrm{H}^{+}$exchange through an amiloride-insensitive pathway Journal of General Physiology 84 565-584

Grootegoed JA, Jamsen R and Vander Molen HJ (1986) Effect of glucose on ATP phosphorylation in rat spermatids Journal of Reproduction and Fertility $\mathbf{7 7}$ 99-107

Hagiwara S and Kawa K (1984) Calcium and potassium currents in spermatogenic cells dissociated from rat seminiferous tubules Journal of Physiology 356 $135 \approx 149$

Hodgkin AL and Katz B (1949) The effect of sodium ions on the electrical activity of the giant axon of the squid Journal of Physiology 108 37-77

Hoffman JF and Laris PC (1974) Determination of membrane potentials in human and amphiuma red blood cells by means of a fluorescent probe Journal of Physiology 239 519-552

Johnstone RM, Laris PC and Eddy AA (1982) The use of fluorescent dyes to measure membrane potentials: a critique Journal of Cell Physiology 112 298-301

Kierszenbaum AL, Libanati CM and Tandler CJ (1971) The distribution of inorganic cations in mouse testis. Electron microscope and microprobe analysis Journal of Cell Biology 48 314-323

Laüger P (1973) Ion transport through pores: a rate theory analysis Biochimica et Biophysica Acta $311423-441$

Li CC (1964) Introduction to Experimental Statistics pp 430-440. McGraw-Hill Book Company, New York

Mita M and Hall PF (1982) Metabolism of round spermatids from rats: lactate as the preferred substrate Biology of Reproduction 26 445-455

Montecucco C, Pozzan T and Rink T (1979) Dicarbocyanine fluorescent probes of membrane potential block lymphocyte capping, deplete cellular ATP and inhibit respiration of isolated mitochondria Biochimica et Biophysica Acta 552 $552-557$

Nakamura M, Fujiwara A, Yasumasu I, Okinaga S and Arai K (1982) Regulation of glucose metabolism by adenine nucleotides in round spermatids from rat testes Journal of Biological Chemistry $25713945-13950$

Nakamura M, Yamaguchi K, Suzuki A, Okinaka S and Arai K (1986) Metabolism of round spermatids: a possible regulation of hexose transport Development Growth and Differentiation 28 499-504

Owen CS (1992) Comparison of spectrum-shifting intracellular $\mathrm{pH}$ probes $5^{\prime}$ (and $6^{\prime}$ )-carboxy-10-dimethyl amino-3-hydroxyspiro[7H-benzo-c] xanthene-7, $1^{\prime}\left(3^{\prime} \mathrm{H}\right.$ )-isobenzofuran- $3^{\prime}$-one and $2^{\prime} 7^{\prime}$-biscarboxyethyl-5-(and 6) carboxy fluorescein Analytical Biochemistry 204 65-71

Reyes JG, Velarde MV, Ugarte R and Benos DJ (1990) Glycolytic component of rat spermatid energy and acid-base metabolism American Journal of Physiology 259 C660-C667

Reyes JG, Santander M, Arrate MP and Benos DJ (1993) Transport and distribution of $\mathrm{Zn}(\mathrm{II})$ in rat spermatids American Journal of Physiology 265 C893-C900

Rink TJ, Montecucco C, Hesketh TR and Tsien RY (1980) Lymphocyte membrane potential assessed with fluorescent probes Biochimica et Biophysica Acta $595 \quad 15-30$

Scheler W and Blank J (1977) Physicochemical fundamentals and thermodynamics of the membrane transport of drugs. In Kinetics of Drug Action pp 3-62 Ed. JM van Rossum. Springer Verlag, New York

Setchell BP and Brooks DE (1988) Anatomy, vasculature, innervation and fluids of the male reproductive tract. In Physiology of Reproduction, pp 753-836 Eds E Knobil, J Neill, LL Ewing, GS Greenwald, CL Markert and DW Pfaff. Raven Press, Ltd, New York

Smith TC (1982) The use of fluorescent dyes to measure membrane potentials: a response Journal of Cellular Physiology 112 302-305 